\title{
Rehabilitation of children with cochlear implant in Iran: A scoping review
}

\author{
Mina Moradi ${ }^{1,2}$, Masoud Fallahi-Khoshknab* ${ }^{1} \mathbb{D}$, Asghar Dalvandi $^{1,2}$, Mohammad Farhadi $^{3}$, Sadat Seyed Bagher Maddah ${ }^{1}$, \\ Eesa Mohammadi ${ }^{4}$
}

Received: 20 Apr 2020

Published: 7 Jun 2021

\begin{abstract}
Background: Recovery of children does not appear on its own after cochlear implantation. Coherent, thoughtful, and comprehensive rehabilitation is needed to achieve complete success. The purpose of this study was to identify the types of rehabilitation interventions for children with cochlear implants that have been performed in Iran.

Methods: A scoping review study was conducted. An electronic search was carried out both in English and Persian. In English, the following keywords were used: cochlear implantation, child, cochlear implants, auditory rehabilitation, deaf, hearing loss, comprehensive, interventions, rehabilitation, and telerehabilitation and a combination of them in ProQuest, PubMed, Science Direct, and Scopus databases, Web of Sciences, Medline and Embase. Persian electronic search was conducted in the Scientific Information Database (SID) of Jihad Daneshgahi, Iran Journals Database (MagIran), and Islamic World Science Citation Database (ISC). Searches were done using articles published until September 25, 2020, and a total of 902 articles were found, of which 14 were directly related to the purpose of the study. Interventional studies were included in the study, and the quality of studies was measured using the Structured Effectiveness Quality Evaluation Scale.

Results: The results showed that using music and rehabilitation equipment, different methods of speech therapy and auditory training, story-based instruction, creative play, family-centered instruction, and occupational therapy are interventions in cochlear implant rehabilitation. Speech therapy accounts for $54 \%$ of the rehabilitation share. The mean number of rehabilitation sessions was 26. These interventions were all somehow effective in children with cochlear implantation; the longer the training duration, the better the results.

Conclusion: The process of cochlear implant rehabilitation in children is multi-professional; auditory training and speech therapy possesses the highest share of rehabilitation. Therefore, it is recommended to develop speech therapy centers in Iran.
\end{abstract}

Keywords: Rehabilitation, Cochlear Implant, Child, Iran

Conflicts of Interest: None declared

Funding: University of Social Welfare and Rehabilitation Sciences

\section{*This work has been published under CC BY-NC-SA 1.0 license. \\ Copyright $\subseteq$ Iran University of Medical Sciences}

Cite this article as: Moradi M, Fallahi-Khoshknab M, Dalvandi A, Farhadi M, Maddah SB, Mohammadi E. Rehabilitation of children with cochlear implant in Iran: A scoping review. Med J Islam Repub Iran. 2021 (7 Jun);35:73. https://doi.org/10.47176/mjiri.35.73

\section{Introduction}

Deafness is called a hidden disability. Hearing loss is the most common type of neurosensory disability, and its incidence is increasing (1). According to the World Health Organization (WHO) in 2017, more than $5 \%$ of the world's population, about 360 million people, 328 million

Corresponding author: Dr Masoud Fallahi-Khoshknab, fallahi@uswr.ac.ir

1. Department of Nursing, University of Social Welfare and Rehabilitation Sciences, Tehran, Iran

2. Department of Nursing, Faculty of Nursing and Midwifery, Tehran Medical sciences, Islamic Azad university, Tehran, Iran

3. ENT and Head \& Neck Research center and department, Hazrat Rasoul Hosipital, The five senses Institute, Iran University of medical sciences, Tehran, Iran

4. Department of Nursing, School of Medical Sciences, Tarbiat Modares University, Tehran, Iran adults, and 32 million kids, suffer hearing loss (2). According to statistics provided by ENT and Head \& Neck Research Center in 2007, approximately 2,100,000 to $3,500,000$ of the Iranian population have moderate to severe hearing impairment(3). Technology facilities are

$\uparrow$ What is "already known" in this topic:

Previous studies have investigated cochlear implant rehabilitation in a single professional field, such as speech therapy and auditory training in Iran.

There is no systematic review on Types of rehabilitation in children with CI.

$\rightarrow$ What this article adds:

Auditory training and speech therapy possesses the highest share of rehabilitation; other aspects of the rehabilitation process have been studied less. 
available for children born with hearing loss, which improve the hearing threshold of these children and enable them to better understand speech and language (4). Audiologists believe that a cochlear implant represents a marvelous medical and engineering success that is more compatible with the human nervous system compared to any other prosthesis (5). In fact, the earliest attempts to assist the deaf in understanding speech began with electrical stimulation of the auditory nerve in the 1950s and 1960s (6). In 1977, the first implantation surgery was carried out on children, and Claude-Henri Chouard implanted two young children, one 10 years old and the other 14 years old in France $(7,8)$. The first young child, a 3-year-old kid, was operated on by Dr. House in 1981 (8).

The first attempts in Iran for cochlear implantation began in Rasool-e-Akram and Amir A'lam Hospitals in 1991. In the same year and in Rasool-e-Akram Hospital, Dr. Farhadi officially launched the project after conducting preliminary studies and preparing protocols for selecting the appropriate candidate for assessment scales and auditory-verbal rehabilitation programs (9). There are currently 11 cochlear implantation centers in Iran (10). Children undergo a rehabilitation program following surgery. This is a surgical supplement program (11). A review of different studies shows that parents are important in the rehabilitation process, and they are important members of the rehabilitation process (12-15). They experience more stress compared to parents having children with normal hearing; they experience the highest level of stress immediately after implantation, usually two years thereafter, and adaptability problems after implantation are their primary source of stress. Studies with quantitative approaches have also shown that the family environment influences the outcomes of cochlear implants in children (16). Reviews also reveal that parents, music, and new technologies are effective in the rehabilitation of these clients (17-20)

One of the challenges in the rehabilitation process is that these children are relatively late in developing their syntax skills compared to their peers (21). Also, comparing the speech intelligibility of cochlear implant children with hearing aids and children with normal hearing demonstrated that speech intelligibility in children with normal hearing was better than cochlear implant children with hearing aids. Hence special rehabilitation is needed to further develop the speech skills of cochlear implant children (22).

Moreover, the most important challenge of comprehensive cochlear implant rehabilitation is the lack of progress in the psycho-social development of these children compared to their hearing peers. Despite academic achieve- ment almost equal to their hearing peers, they report loneliness and lack of intimate friendships in integrated environments; they often have difficulty in social and emotional functions and communicating with other children (23). Special attention has been paid to the rehabilitation of these children in recent years, and various studies have been conducted in different fields. Most studies have investigated cochlear implant rehabilitation in a single professional field, such as speech therapy and auditory training. However, no study has comprehensively examined the rehabilitation of children with a cochlear implant, considering the share of each profession in the cochlear implantation team. Rehabilitation is also influenced by background, context, type of disease, culture, the severity of illness, and age of clients (24). World Health Organization states that the establishment, modification of national rehabilitation programs and the capacity to implement these plans to improve access to rehabilitation is important (25).

In order to clarify different methods of rehabilitation, the present study set to systematically what kind of rehabilitation interventions for children with cochlear implants have been performed in Iran and which dimensions of rehabilitation are paid less and which dimensions are paid more attention in Iran. We believe that the results of this study will hopefully give us more insight into the rehabilitation of these children and help policymakers and researchers adopt rehabilitation sitrategies.

\section{Methods}

All studies published in English and Persian from 1975 to September 25th, 2020, which examined the rehabilitation of children with a cochlear implant, were systematically reviewed in accordance with the PRISMA guidelines.

This study was conducted using a scoping review method. To obtain scientific documentation and evidence relevant to the study, an electronic search was carried out in English using the following keywords: Mesh, cochlear implantation, child, cochlear implants, auditory rehabilitation, deaf, hearing loss, comprehensive, interventions, rehabilitation, and telerehabilitation and a combination of them in ProQuest, PubMed, Science Direct, and Scopus databases, Web of Sciences, Medline and Embase. Persian electronic search was conducted in the Scientific Information Database (SID) of Jihad Daneshgahi, Iran Journals Database (MagIran), and Islamic World Science Citation Database (ISC). The searches for this study were done using articles published until September 25th, 2020. The search method in the PulbMed database is given in Box 1. The main question to answer was what kind of rehabilitation interventions are performed in cochlear im-

Box 1. PubMed Search Method




plant children in Iran.

\section{Inclusion criteria}

All quantitative interventional articles and articles published in English and Persian that examined different areas of rehabilitation in pre-lingual cochlear implant deaf children (0-16 years old) were included in the study.

\section{Exclusion criteria}

Articles examining rehabilitation of adults, the elderly, and children with various syndromes, studies with lack of access to full text, qualitative articles, observational studies, gray literature (reports, thesis, and conferences), and studies on children with mental health problems were excluded.

\section{Data extraction}

A form, including variables of the first author, year of publication, the purpose of study, type of intervention, sample size, and the most important findings, was used for data extraction. Data were extracted independently by two authors (MF and MM), and if the two authors disagreed, the article was judged by the second author (EM). After completing this form, the results of the articles' analyses were summarized and reported (Table 1).

\section{Critical review of articles}

The quality of the studies compiled by two authors (MM and MF) was reviewed, and disagreements were resolved by the second author (EM). The methodological quality of the interventions was assessed based on the SEQES tool used in various interventional studies. The tool consisted of 24 items. Each item had a score ranging from 0 to 2; 0-16 score indicated low-quality, 17-32 score average-quality, and 33-48 score indicated high-quality methodology. The basis of the studies was analyzed separately based on the status of the method's quality (Table 2).

\section{Results}

According to the inclusion criteria, 902 articles were initially selected; 20 articles were excluded as they were duplicates in different databases; 845 articles were excluded after assessing their titles and abstracts, these articles were about cochlear implants in adults or the treatment of hearing loss, and five other articles were excluded due to evaluation of children with pre-lingual hearing loss along with other syndromes. Four review articles and 14 articles related to rehabilitation but having no intervention were excluded. The process of selecting articles is illustrated in the PRISMA flowchart (Fig. 1).

A total of 14 articles have been reviewed in this study. Table 1 summarizes the language of studies, objectives, sample size, study method, and the results. Of the 14 articles reviewed, three were published in foreign journals and nine in domestic journals in Persian.

Among the articles reviewed, one study was about music, one about speech therapy, two articles about familycentered instruction, two studies for auditory training, one study for occupational therapy, one study for storytelling, one article about the creative presentation of a study, one study regarding the visual and auditory use, and one for the impact of rehabilitation. In the articles, the average number of rehabilitation sessions was 26 (minimum 6 and maximum 80 sessions).

Table 3 shows the number of rehabilitation articles and sessions in terms of various types of rehabilitation; of the 14 articles reviewed, only $32 \%$ of the articles (four articles) referred to the length of rehabilitation. Shah-Panah et al. utilized 24 sessions of music therapy along with 6 months of rehabilitation. Qassimzadeh et al. reported performing a creative play in 20 weeks; Hamedi et al. elaborated on 6 weeks of occupational therapy, and Hashemi et al. referred to 80 sessions of auditory training within a year. The highest duration of rehabilitation was related to auditory training in 80 sessions within a year. Overall, hearing and speech training sessions included the most rehabilitation sessions (54\%).

\section{Discussion}

This is the first systematic review that has comprehensively examined interventions in the rehabilitation of children with a cochlear implant. Nearly 15 percent of articles have examined family-related factors. As parents and family are important components of the rehabilitation team of children with a cochlear implant (12), in the current study, most studies were found to have focused on the role of the family in child rehabilitation and family-centered education in cochlear implantation.

One of the studies had investigated the impact of music on the rehabilitation of children with cochlear implants. Music stimulates many areas of the brain, in addition to the auditory cortex. Studies show that music induces the secretion of different types of neurotransmitters and mediators in the central and peripheral nervous system, which affects neurons' metabolism, enhances synaptic learning, causes structural changes in synapses, and increases the production of neurons. Using basic musical concepts at the beginning of the hearing age along with devices such as cochlear implants can make the listening experience more enjoyable for these children; so that they are more willing to use their sense of hearing and enjoy this feeling in a completely natural way (26). Hosseini et al. (2016) also demonstrated the positive effects of music therapy combined with traditional therapy on speech clarity of children with a cochlear implant. Therefore, music classes in rehabilitation centers, if possible, can improve the rehabilitation of these children (27).

Studies have focused on different ways of improving speech in children with a cochlear implant, including cued speech and story-based instruction. The cued speech method makes speech perception very easy. It also improves lip-reading skills and the ability to use residual hearing in hearing-impaired children. Cued speech enhances the ability to communicate, understand, and differentiate speech from an early age and improves speech and the ability to benefit from cochlear implantation. Cued speech is one of the verbal forms that makes all sounds visible and accessible (28). 


\begin{tabular}{|c|c|c|c|c|c|c|c|c|c|c|}
\hline $\begin{array}{l}\text { Article } \\
\text { Number }\end{array}$ & $\begin{array}{l}\text { Article lan- } \\
\text { guage }\end{array}$ & Authors/Year & Purpose & Group 1 intervention & Group 2 intervention & Group 3 & Study method & Sample size & Summary of findings & $\begin{array}{l}\text { Quality of } \\
\text { studies }\end{array}$ \\
\hline 1 & Persian & $\begin{array}{c}\text { Hashemi } \\
\text { et al. } 2011(41)\end{array}$ & $\begin{array}{l}\text { Evaluation of the } \\
\text { child's development } \\
\text { of language skills } \\
\text { such as general } \\
\text { information devel- } \\
\text { opment, calculation, } \\
\text { vocabulary and } \\
\text { comprehension } \\
\text { following surgery } \\
\text { and rehabilitation }\end{array}$ & $\begin{array}{l}\text { intervention } 23 \text { chil- } \\
\text { dren of the verbal } \\
\text { section of Wechsler } \\
\text { scale }\end{array}$ & - & - & $\begin{array}{l}\text { Quasi- } \\
\text { experimental in- } \\
\text { tervention }\end{array}$ & $\begin{array}{l}23 \text { children } \\
\text { with cochlear } \\
\text { implant }\end{array}$ & $\begin{array}{l}\text { Following surgery and rehabilita- } \\
\text { tion program, the level of verbal } \\
\text { intelligence of children with } \\
\text { cochlear implants increased, but } \\
\text { did not reach the level of normal } \\
\text { children of their age. One of the } \\
\text { influential factors was the age of } \\
\text { the child and the level of family } \\
\text { education. There was no signifi- } \\
\text { cant correlation between verbal } \\
\text { and non-verbal intelligence. }\end{array}$ & Average \\
\hline 2 & English & $\begin{array}{c}\text { Zamani et al. } 2018 \\
(42)\end{array}$ & $\begin{array}{l}\text { Evaluation of story- } \\
\text { based language } \\
\text { learning in storytell- } \\
\text { ing structures of } \\
\text { children with coch- } \\
\text { lear implant }\end{array}$ & $\begin{array}{l}\text { Group } 1 \text { in } 24 \text { 1-hour } \\
\text { sessions of NBLI } \\
\text { therapy group }\end{array}$ & $\begin{array}{l}\text { Participants in group } 2 \\
\text { each attended } 241- \\
\text { hour sessions of private } \\
\text { NBLI training. }\end{array}$ & $\begin{array}{l}\text { Group } 3 \\
\text { participated } \\
\text { in } 2424- \\
\text { hour ses- } \\
\text { sions of } \\
\text { conventional } \\
\text { speech } \\
\text { therapy } \\
\text { (CST). }\end{array}$ & $\begin{array}{l}\text { Randomized con- } \\
\text { trol } \\
\text { trial }\end{array}$ & $\begin{array}{l}36 \text { children } \\
\text { with cochlear } \\
\text { implant }\end{array}$ & $\begin{array}{l}\text { Group } 1 \text { and group } 2 \text { had signifi- } \\
\text { cantly better results than group } 3 \\
\text { in all components of the narrative } \\
\text { speech structure at } T 1 \quad(P \geq 0.04) \\
\text { and T2 ( } P \geq 0.04) \text {, respectively, } \\
\text { compared to T0. But, no differ- } \\
\text { ence was found between NBLI } \\
\text { approaches ( } P>0.05) \text {. All three } \\
\text { intervention programs signifi- } \\
\text { cantly improved the overall } \\
\text { structure of speech narrative in } \\
\text { children with cochlear implant. }\end{array}$ & High \\
\hline 3 & English & $\begin{array}{c}\text { Zanjani et al. } 2013 \\
\text { (43) }\end{array}$ & $\begin{array}{l}\text { Comparison of lan- } \\
\text { guage, auditory, and } \\
\text { speech development } \\
\text { in children trained } \\
\text { with one sense (audi- } \\
\text { tory) and two senses } \\
\text { (auditory and sight) }\end{array}$ & $\begin{array}{c}10 \text { people only } \\
\text { trained with auditory } \\
\text { sense }\end{array}$ & $\begin{array}{l}11 \text { individuals trained } \\
\text { with two auditory and } \\
\text { sight senses }\end{array}$ & - & $\begin{array}{l}\text { Randomized con- } \\
\text { trolled trial }\end{array}$ & $\begin{array}{l}22 \text { children } \\
\text { with cochlear } \\
\text { implant }\end{array}$ & $\begin{array}{l}\text { Training with one sense (audito- } \\
\text { ry training) and with two-senses } \\
\text { (auditory and visual training) are } \\
\text { both effective for children with } \\
\text { cochlear implants, and there is no } \\
\text { significant difference between } \\
\text { them. }\end{array}$ & High \\
\hline
\end{tabular}




\begin{tabular}{|c|c|c|c|c|c|c|c|c|c|c|}
\hline $\begin{array}{c}\text { Article } \\
\text { Number } \\
\end{array}$ & $\begin{array}{l}\text { Article lan- } \\
\text { guage }\end{array}$ & Authors/Year & Purpose & Group 1 intervention & Group 2 intervention & Group 3 & Study method & Sample size & Summary of findings & $\begin{array}{c}\begin{array}{c}\text { Quality of } \\
\text { studies }\end{array} \\
\end{array}$ \\
\hline 4 & Persian & $\begin{array}{c}\text { Shahpanah et al. } \\
2016(47)\end{array}$ & $\begin{array}{l}\text { Evaluation of the } \\
\text { effectiveness of } \\
\text { music therapy on } \\
\text { enhancing reading } \\
\text { ability in primary } \\
\text { school children with } \\
\text { cochlear implant }\end{array}$ & $\begin{array}{l}10 \text { people randomly } \\
\text { assigned to experi- } \\
\text { mental music therapy } \\
\text { group with rehabili- } \\
\text { tation } \\
24 \text { sessions in } 6 \\
\text { months in music } \\
\text { therapy sessions with } \\
\text { rehabilitation }\end{array}$ & $\begin{array}{l}10 \text { people in the con- } \\
\text { trol group (regular } \\
\text { rehabilitation ses- } \\
\text { sions) }\end{array}$ & - & $\begin{array}{l}\text { Experimental } \\
\text { study with pretest- } \\
\text { posttest and con- } \\
\text { trol group }\end{array}$ & $\begin{array}{l}30 \text { children } \\
\text { with cochlear } \\
\text { implant }\end{array}$ & $\begin{array}{l}\text { According to the findings, mu- } \\
\text { sic therapy measures are effec- } \\
\text { tive on the reading skill of pre- } \\
\text { school children with cochlear } \\
\text { implants. }\end{array}$ & High \\
\hline 5 & Persian & Amrayi et al. (48) & $\begin{array}{l}\text { The purpose of this } \\
\text { study was to inves- } \\
\text { tigate the effect of } \\
\text { family-centered } \\
\text { education program } \\
\text { of social skills on } \\
\text { improving social } \\
\text { skills of children } \\
\text { with cochlear im- } \\
\text { plant. }\end{array}$ & $\begin{array}{l}\text { Participants of } 12 \\
60-75 \text {-min session } \\
\text { group undergoing } \\
\text { social skills training }\end{array}$ & - & - & Experimental type & $\begin{array}{l}16 \text { families } \\
\text { with children } \\
\text { with cochlear } \\
\text { implant }\end{array}$ & $\begin{array}{l}\text { The results showed that family- } \\
\text { centered training program of } \\
\text { social skills had a positive and } \\
\text { significant effect on assertive- } \\
\text { ness }(\mathrm{P}<0.01) \text {, self-control } \\
(\mathrm{P}<0.01) \text { and overall social } \\
\text { skills }(\mathrm{P}<0.01) \text {, but it had not } \\
\text { significant effect on cooperation } \\
\text { and participation skills } \\
(\mathrm{P}>0.05) \text {. }\end{array}$ & Average \\
\hline 7 & English & $\begin{array}{l}\text { Jeddi et al. } 2014 \\
\text { (49) }\end{array}$ & $\begin{array}{l}\text { Rehabilitation of } \\
\text { children with coch- } \\
\text { lear implant }\end{array}$ & $\begin{array}{l}\text { Evaluation of the } \\
\text { benefits of auditory } \\
\text { rehabilitation regard- } \\
\text { ing cognitive, social } \\
\text { communication, and } \\
\text { motor skills }\end{array}$ & - & - & Intervention & $\begin{array}{l}15 \text { children } \\
\text { with cochlear } \\
\text { implants }\end{array}$ & $\begin{array}{l}\text { Auditory rehabilitation enhanc- } \\
\text { es cognitive, social communica- } \\
\text { tion, and motor skills in children } \\
\text { with cochlear implants. }\end{array}$ & Average \\
\hline
\end{tabular}


Rehabilitation in cochlear implant

\begin{tabular}{|c|c|c|c|c|c|c|c|c|c|c|}
\hline $\begin{array}{l}\text { Article } \\
\text { Number }\end{array}$ & $\begin{array}{c}\text { Article } \\
\text { language }\end{array}$ & Authors/Year & Purpose & Group 1 intervention & $\begin{array}{l}\text { Group } 2 \text { inter- } \\
\text { vention }\end{array}$ & Group 3 & Study method & Sample size & Summary of findings & $\begin{array}{c}\text { Quality of } \\
\text { studies }\end{array}$ \\
\hline 8 & Persian & $\begin{array}{l}\text { Qasemzadeh et } \\
\text { al. } 2017 \text { (37) }\end{array}$ & $\begin{array}{l}\text { The effect of an } \\
\text { intervention pro- } \\
\text { gram based on } \\
\text { creative-play on } \\
\text { children's language } \\
\text { skills with cochlear } \\
\text { implant }\end{array}$ & $\begin{array}{c}\text { The intervention } \\
\text { consisted of } 2090- \\
\text { minute sessions once } \\
\text { a week }\end{array}$ & - & - & $\begin{array}{l}\text { Pre-test, post-test } \\
\text { intervention }\end{array}$ & $30 \mathrm{CI}$ & $\begin{array}{l}\text { Creating play conditions and } \\
\text { teaching linguistic structures } \\
\text { had an indirect considerable } \\
\text { impact on the language skills of } \\
\text { these children. }\end{array}$ & High \\
\hline 9 & Persian & $\begin{array}{l}\text { Manuchehri et al. } \\
2011(50)\end{array}$ & $\begin{array}{c}\text { Evaluation of the } \\
\text { progress of speech } \\
\text { perception in chil- } \\
\text { dren with cochlear } \\
\text { implant }\end{array}$ & $\begin{array}{l}10-43 \text { sessions with } \\
\text { an average of } 23 \\
\text { sessions 1-hour of } \\
\text { auditory training } \\
\text { rehabilitation }\end{array}$ & - & - & Intervention & $\begin{array}{l}30 \text { children } \\
\text { with cochlear } \\
\text { implants }\end{array}$ & $\begin{array}{l}\text { Sound awareness is a rapidly } \\
\text { evolving ability, requiring } \\
\text { broader training to access other } \\
\text { speech and non-speech differ- } \\
\text { entiation capabilities, especially } \\
\text { speech comprehension, which } \\
\text { is the last and most important } \\
\text { ability for communication. }\end{array}$ & Average \\
\hline 10 & Persian & $\begin{array}{l}\text { Hamedi et al. } \\
2017 \text { (38) }\end{array}$ & $\begin{array}{l}\text { Evaluation of task- } \\
\text { based occupational } \\
\text { therapy on Interven- } \\
\text { tions on balance } \\
\text { performance of } \\
\text { hearing-impaired } \\
\text { children with coch- } \\
\text { lear implant }\end{array}$ & $\begin{array}{l}6 \text { weeks, } 3 \text { sessions } \\
\text { per week and } 30 \\
\text { minutes per session } \\
\text { in the intervention } \\
\text { group }\end{array}$ & & - & $\begin{array}{c}\text { Quasi- } \\
\text { experimental }\end{array}$ & $\begin{array}{l}30 \text { children } \\
\text { with cochlear } \\
\text { implants }\end{array}$ & $\begin{array}{l}\text { Task-based occupational thera- } \\
\text { py interventions can improve } \\
\text { balance control in children with } \\
\text { cochlear implants. }\end{array}$ & High \\
\hline 11 & Persian & $\begin{array}{l}\text { Hasanzadeh et al. } \\
2017(40)\end{array}$ & $\begin{array}{c}\text { Evaluation of the } \\
\text { effectiveness of } \\
\text { auditory rehabilita- } \\
\text { tion program devel- } \\
\text { oped as Navayesh } \\
\text { on primary commu- } \\
\text { nication and lan- } \\
\text { guage skills of } \\
\text { children candidate } \\
\text { for cochlear implan- } \\
\text { tation }\end{array}$ & $\begin{array}{l}\text { Running Navayesh } \\
\text { rehabilitation pro- } \\
\text { gram in } 5 \text { steps and } \\
6 \text { group sessions }\end{array}$ & $\begin{array}{l}\text { The control } \\
\text { group had no } \\
\text { intervention }\end{array}$ & - & $\begin{array}{c}\text { Quasi- } \\
\text { experimental }\end{array}$ & $\begin{array}{l}62 \text { children } \\
\text { with cochlear } \\
\text { implants }\end{array}$ & $\begin{array}{l}\text { The program was effective in } \\
\text { enhancing communication } \\
\text { abilities, auditory perception, } \\
\text { and speech production of deaf } \\
\text { children in comparison with } \\
\text { the control group. The follow- } \\
\text { up of sustainability results } \\
\text { revealed the effectiveness of } \\
\text { the program. Given the in- } \\
\text { creasing decline in the diagno- } \\
\text { sis age of hearing loss, using } \\
\text { this program can be effective } \\
\text { in the auditory rehabilitation } \\
\text { of deaf children. }\end{array}$ & High \\
\hline
\end{tabular}

$6 \quad$ http://mjiri.iums.ac.ir

Med J Islam Repub Iran. 2021 (7 Jun); 35:73. 


\begin{tabular}{|c|c|c|c|c|c|c|c|c|c|c|}
\hline $\begin{array}{l}\text { Article } \\
\text { Number }\end{array}$ & $\begin{array}{c}\text { Article } \\
\text { language }\end{array}$ & Authors/Year & Purpose & $\begin{array}{l}\text { Group } 1 \text { interven- } \\
\text { tion } \\
\end{array}$ & $\begin{array}{l}\text { Group } 2 \text { inter- } \\
\text { vention }\end{array}$ & Group 3 & Study method & Sample size & Summary of findings & $\begin{array}{c}\text { Quality of } \\
\text { studies }\end{array}$ \\
\hline 12 & Persian & $\begin{array}{l}\text { Hashemi et al. } \\
2007 \text { (51) }\end{array}$ & $\begin{array}{l}\text { Improvement of } 30 \\
\text { patients in Fars } \\
\text { Center in auditory, } \\
\text { speech, and lan- } \\
\text { guage skills was } \\
\text { investigated. }\end{array}$ & $\begin{array}{c}\text { Hearing skills, } \\
\text { language acquisi- } \\
\text { tion, and speech } \\
\text { comprehension } \\
80 \text { sessions during a } \\
\text { year }\end{array}$ & & & Intervention & $\begin{array}{l}30 \text { children } \\
\text { with cochlear } \\
\text { implants }\end{array}$ & $\begin{array}{l}\text { There is a close relationship } \\
\text { between the low age of the } \\
\text { child and progress in a rehabil- } \\
\text { itation program. The longer the } \\
\text { duration of post-surgical reha- } \\
\text { bilitation, the better the child's } \\
\text { performance in learning audi- } \\
\text { tory, language, and speech } \\
\text { skills. }\end{array}$ & High \\
\hline 13 & English & $\begin{array}{l}\text { Monshizadeh } \\
\text { et al } 2019 \text { (44) }\end{array}$ & $\begin{array}{l}\text { Comaring of rou- } \\
\text { tine language reha- } \\
\text { bilitation and } \\
\text { new } \\
\text { intervention proto- } \\
\text { col specifically } \\
\text { designed to en- } \\
\text { hance receptive } \\
\text { vocabulary devel- } \\
\text { opment in cochlear } \\
\text { implanted children. }\end{array}$ & $\begin{array}{c}\text { a routine auditory- } \\
\text { verbal intervention } \\
\text { and a new cognitive } \\
\text { based intervention } \\
\text { protocol }\end{array}$ & $\begin{array}{l}\text { a routine audito- } \\
\text { ry-verbal inter- } \\
\text { vention }\end{array}$ & & $\begin{array}{l}\text { prospective ex- } \\
\text { perimental study }\end{array}$ & $\begin{array}{l}\text { 51 cochlear } \\
\text { implant chil- } \\
\text { dren }\end{array}$ & $\begin{array}{l}\text { New protocol was more effec- } \\
\text { tive }\end{array}$ & High \\
\hline 14 & English & $\begin{array}{l}\text { Mehrkian etal } \\
2019(46)\end{array}$ & $\begin{array}{l}\text { to evaluate the } \\
\text { effect of wireless } \\
\text { Remote Micro- } \\
\text { phones on speech } \\
\text { discrimination } \\
\text { scores in noise in } \\
\text { child CI users. }\end{array}$ & $\begin{array}{l}\text { using the Words-in- } \\
\text { Noise test at a con- } \\
\text { stant signal-to-noise } \\
\text { ratio of } d B \text {, in the } \\
\text { presence and ab- } \\
\text { sence of a wireless } \\
\text { RM. }\end{array}$ & & & Interventional & $\begin{array}{l}20 \text { children } \\
\text { with cochlear } \\
\text { implants }\end{array}$ & $\begin{array}{l}\text { wireless Remote Microphone } \\
\text { was effective }\end{array}$ & High \\
\hline
\end{tabular}




\begin{tabular}{|c|c|c|c|c|c|c|c|c|c|c|c|c|c|c|}
\hline Articles & 1 & 2 & 3 & 4 & 5 & 6 & 7 & 8 & 9 & 10 & 11 & 12 & 13 & 14 \\
\hline \multicolumn{15}{|l|}{ Study question } \\
\hline $\begin{array}{l}\text { 1. Was relevant background work cited to establish a foundation for the research question? } \\
\text { Study design }\end{array}$ & 2 & 2 & 2 & 2 & 2 & 2 & 2 & 2 & 2 & 2 & 2 & 2 & 2 & 2 \\
\hline 2. Was a comparison group used? & 0 & 2 & 2 & 2 & 0 & 2 & 0 & 2 & 2 & 2 & 2 & 0 & 2 & 2 \\
\hline 3. Was patient status at more than 1 time point considered? & 2 & 1 & 2 & 2 & 2 & 1 & 2 & 2 & 2 & 2 & 2 & 0 & 2 & 0 \\
\hline 4. Were data collection performed prospectively? & 2 & 2 & 2 & 2 & 2 & 2 & 2 & 2 & 2 & 2 & 2 & 2 & 2 & 2 \\
\hline 5. Were patients randomized to groups? & 0 & 2 & 2 & 0 & 0 & 0 & 0 & 2 & 2 & 2 & 2 & 0 & 2 & 0 \\
\hline 6. Were patients blinded to the extent possible? & 0 & 0 & 0 & 0 & 0 & 0 & 0 & 0 & 0 & 2 & 2 & 2 & 2 & 0 \\
\hline 7. Were treatment providers randomized to the extent possible? & 0 & 0 & 2 & 0 & 0 & 0 & 0 & 0 & 0 & 1 & 1 & 1 & 2 & 1 \\
\hline \multicolumn{15}{|l|}{ Subjects } \\
\hline 9. Did sampling procedures minimize sample/collection biases? & 2 & 2 & 2 & 2 & 2 & 2 & 1 & 2 & 2 & 2 & 2 & 2 & 2 & 2 \\
\hline 10. Were inclusion/exclusion criteria defined? & 2 & 1 & 2 & 2 & 2 & 1 & 1 & 0 & 2 & 2 & 2 & 2 & 2 & 2 \\
\hline 11. Was an appropriate enrollment obtained? & 2 & 2 & 2 & 2 & 2 & 2 & 2 & 2 & 2 & 2 & 2 & 2 & 2 & 2 \\
\hline 12. Was appropriate retention/follow-up obtained? & 1 & 2 & 2 & 2 & 2 & 2 & 2 & 2 & 2 & 2 & 2 & 2 & 2 & 2 \\
\hline \multicolumn{15}{|l|}{ Intervention } \\
\hline 13. Was the intervention applied according to established principles? & 2 & 2 & 2 & 2 & 2 & 2 & 2 & 2 & 2 & 2 & 2 & 2 & 2 & 2 \\
\hline 14. Were biases due to the treatment provider minimized? & 1 & 1 & 1 & 1 & 1 & 1 & 1 & 1 & 2 & 2 & 2 & 2 & 2 & 2 \\
\hline 15. Was the intervention compared with the appropriate comparator? & 0 & 2 & 2 & 2 & 0 & 2 & 0 & 2 & 2 & 2 & 2 & 0 & 2 & 1 \\
\hline \multicolumn{15}{|l|}{ Outcomes } \\
\hline 16. Was an appropriate primary outcome defined? & 2 & 2 & 2 & 2 & 2 & 2 & 1 & 1 & 2 & 2 & 2 & 2 & 2 & 2 \\
\hline 17. Was an appropriate secondary outcome considered? & 0 & 2 & 1 & 2 & 2 & 2 & 2 & 2 & 2 & 2 & 2 & 1 & 1 & 0 \\
\hline 18. Was an appropriate follow-up period incorporated? & 0 & 2 & 0 & 0 & 2 & 2 & 2 & 2 & 2 & 2 & 2 & 0 & 2 & 0 \\
\hline $\begin{array}{l}\text { Analysis } \\
\text { 19. Was an appropriate statistical test performed to indicate differences related to the in- } \\
\text { tervention? }\end{array}$ & 0 & 2 & 2 & 2 & 2 & 2 & 2 & 2 & 2 & 2 & 2 & 2 & 2 & 2 \\
\hline 20. Was it established that the study had significant power to identify treatment effects? & 1 & 2 & 1 & 1 & 1 & 1 & 1 & 1 & 2 & 2 & 2 & 2 & 2 & 2 \\
\hline 21. Was the size and significance of the effects reported? & 2 & 2 & 2 & 1 & 1 & 1 & 1 & 1 & 2 & 2 & 2 & 2 & 2 & 2 \\
\hline 22. Were missing data accounted for and considered in interpreting results? & 2 & 0 & 0 & 0 & 0 & 0 & 0 & 0 & 0 & 0 & 0 & 0 & 0 & 0 \\
\hline $\begin{array}{l}\text { 23. Were clinical and practical significance considered in interpreting results? } \\
\text { Recommendations }\end{array}$ & 2 & 2 & 2 & 2 & 2 & 2 & 1 & 2 & 2 & 2 & 2 & 2 & 2 & 2 \\
\hline $\begin{array}{l}\text { 24. Were the conclusions/clinical recommendations supported by the study objectives, } \\
\text { analysis, and results? }\end{array}$ & 2 & 2 & 2 & 2 & 1 & 2 & 1 & 2 & 2 & 2 & 2 & 2 & 2 & 2 \\
\hline Total & 28 & 38 & 38 & 34 & 31 & 34 & 27 & 35 & 41 & 44 & 44 & 34 & 45 & 34 \\
\hline
\end{tabular}




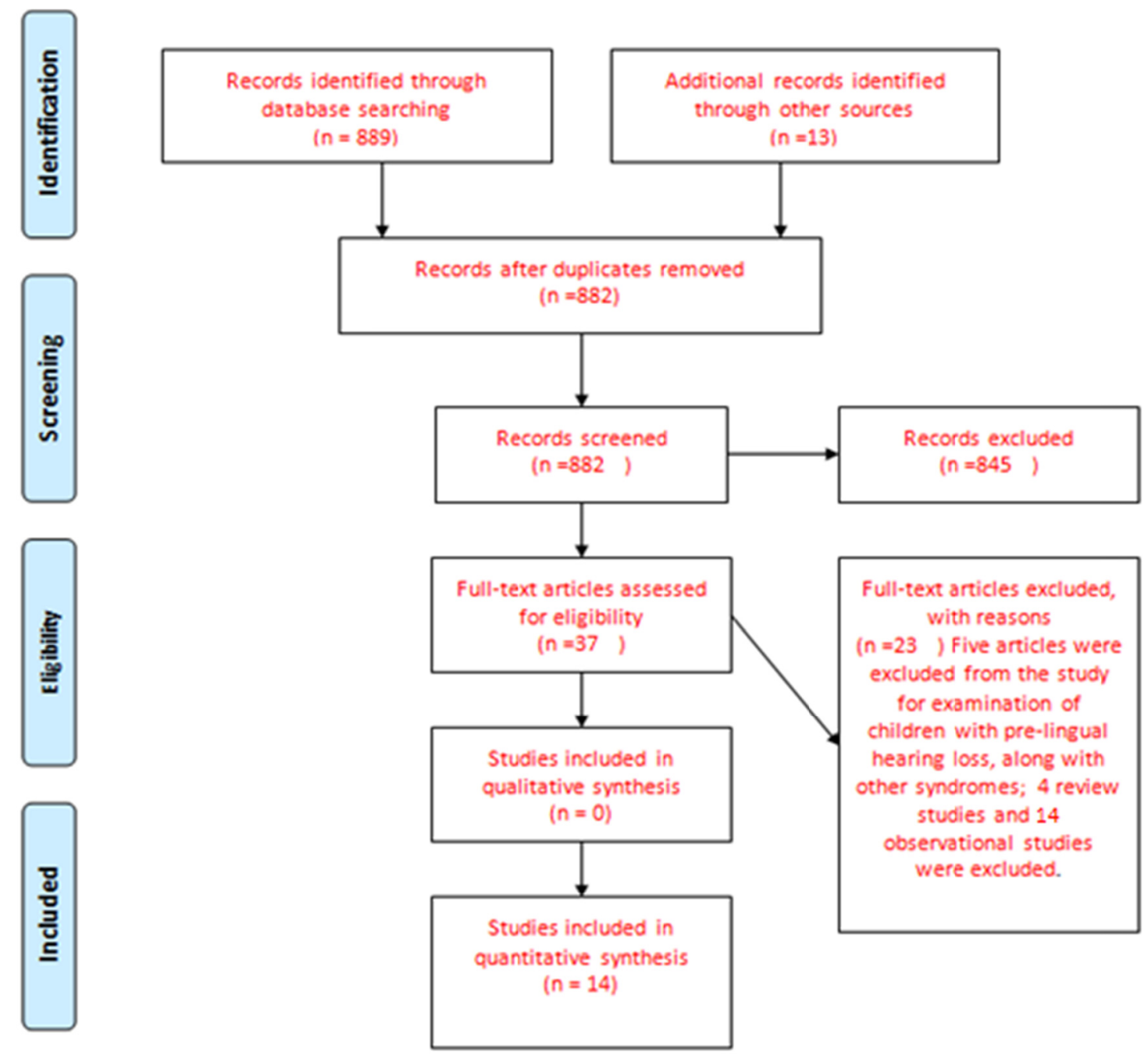

Fig. 1. PRISMA flowchart for selecting study articles

The study of Cochrane, Lalasaso, and Eden (2008) on hearing-impaired children showed that those who were exposed to cued speech training scored higher on phonological awareness and reading ability compared to the group undergoing oral instruction (29).

One quick method to examine the linguistic structure is story-telling, which is faster than other methods regarding execution and analysis. Story-telling or narrative examines spoken language in a natural context that demonstrates spoken information and skill in the expression of elements such as semantics, working memory, and general knowledge (28). Therefore, educational interventions, story-telling, and cued speech can be helpful for these children and improve their speech.

A number of studies focused on the instruction of families. The decrease in the diagnosis age in the first week after birth and cochlear implantation at about 10 months of age confirm this; therefore, parents should play a central role in their child's rehabilitation as a parent-therapist. In fact, families are a key element in the rehabilitation of children with a cochlear implant. Obviously, a deaf child's birth causes parents to feel more responsibility towards their child and assume additional roles apart from parenting; hence they spend a lot of time for the child's rehabilitation. This increases parenting stress in parents; on the other hand, families need to obitain information about their child's hearing loss. However, inadequate and inaccurate information can sometimes affect the way a deaf child is raised (30), so considering families is crucial. This issue has been considered in recent years in Iran, and familycentered instruction programs are being held for families at Iran's Cochlear Implant Center (6). These findings are consistent with works done by Muller (2000), Desjardin (2003), and Yoshinaga-Itano (2003) with respect to the effect of parent-centered interventions on increasing selfconfidence and reducing parental stress, and consequently enhancing communication skills of deaf children (31, 32, and 33).

Two articles examined auditory training; factors that influence the outcome of the implantation are numerous, and some factors, such as intelligence quotient, are not variable. However, some factors are controllable and may be variable to improve the likelihood of higher levels of success. Listening and speaking skills do not appear in 


\begin{tabular}{|c|c|c|c|c|c|c|}
\hline Type of rehabilitation & $\begin{array}{c}\text { Number of } \\
\text { Persian articles }\end{array}$ & $\begin{array}{l}\text { Number of } \\
\text { English } \\
\text { articles }\end{array}$ & Total & $\begin{array}{l}\text { Percentage of } \\
\text { articles }\end{array}$ & $\begin{array}{c}\text { Frequency of } \\
\text { rehabilitation } \\
\text { sessions }\end{array}$ & $\begin{array}{c}\text { Percentage of } \\
\text { rehabilitation } \\
\text { sessions }\end{array}$ \\
\hline Story telling & - & 1 & 1 & 7.14 & 24 & 10.34 \\
\hline enhance receptive vocabulary & & 1 & 1 & 7.14 & - & \\
\hline Speech therapy and auditory training & 3 & - & 3 & 21.43 & 127 & 54.47 \\
\hline Music & 1 & 0 & 1 & 7.14 & 24 & 10.34 \\
\hline Family-centered education & 2 & - & 2 & 14.29 & 18 & 7.75 \\
\hline Creative play & 1 & - & 1 & 7.14 & 20 & 8.62 \\
\hline Occupational Therapy & 1 & - & 1 & 7.14 & 18 & 7.75 \\
\hline The impact of rehabilitation & 1 & 1 & 2 & 14.29 & - & - \\
\hline Use of sight-hearing & - & 1 & 1 & 7.14 & - & - \\
\hline Wireless Remote Microphone & & 1 & 1 & 7.14 & 1 & 0.43 \\
\hline total & 9 & 5 & 14 & 100 & 232 & 100 \\
\hline
\end{tabular}

children following implantation on their own, and consistent and thoughtful rehabilitation is needed to instruct them on how to use the electrical signal of the device for speech recognition purposes and speech and language acquisition (34). Auditory training paves the way for children in a variety of ways, although auditory training is an important part of the rehabilitation of children with a cochlear implant. Perhaps the reason for the small number of these studies can be attributed to the overlap of auditory training studies and speech therapy in the country.

In this study, one study focused on creative play, which is one of the methods of rehabilitation of children with a cochlear implant. One of the ways to increase these skills in children is to use art therapy techniques. Art therapy is a method created for mental health that uses the creative method of creating art to enhance the physical, psychological, and emotional health of individuals of all ages (35). Kunkle-Miller investigated the effectiveness of puppet play therapy on communication skills of hearing-impaired pre-school children and stated that using this method had a significant impact on enhancing the communication skills of these children (36). Creative play with an in-context language learning approach provides children with an opportunity to understand what is happening in the story via imagining the real situation, and in order to play a better role, they should indirectly require themselves to use appropriate sentences and structures (35). In Iran, there are a limited number of rehabilitation centers called creative play (37).

In case of disabilities associated with other rehabilitation groups, they come into action like occupational therapists. For example, many hearing-impaired children have marked deficits in controlling balance, and some studies have reported impaired balance function in children with a cochlear implant (38). Occupational therapies and taskbased interventions can improve the performance of these children. A bilateral cochlear implant improves the emotional perception of music compared to a unilateral cochlear implant (39).

The rehabilitation program for children undergoing cochlear implant surgery is a major part of the treatment process. Child rehabilitation should be designed to include all communication skills such as listening, speaking, perception, and language use. This program includes increased listening attention, comprehension, integration, and speech production (40).
In the present study, the most used rehabilitation in these children is speech therapy and auditory training, which accounts for more than half of the rehabilitation contribution in children with a cochlear implant. Hashemi et al. explored auditory training: 1) sound detection A) through conditioned play response in the child at this level, Spontaneous Alerting Response, B) the child develops some behaviors spontaneously, such as sound search, head rotation towards the sound, etc.; the main purpose of sound detection training is to develop a spontaneous response in the individual. 2) Discrimination of sound: at this level, first, non-verbal difference, similarity, and/or discrimination are usually used. The other part of training at this level is discrimination of the number of vowels and consonants and endurance, intensity, and frequency training. 3) Identification: at this point, segmental and suprasegmental speech parameters are considered. Cases evaluated with respect to supra-segmental speech parameters include A) the speech prosodly pattern, B) the loudness and intensity of the sound, C) sound identification of men, women, and children (frequency). The recognition of segmental speech parameters requires a higher level of auditory perception; training performed at this level include: A) identification of words that differ in the number of syllables, B) identification of words that are different in vowel and consonant, C) identification of the key elements in a phrase and sentence identification; in the identification phase, first, closed-class and then open-class words were used. It should be noted that vocabulary should D) answer the questions of language training E) understand the practices and activities of these training at both pre-verbal and verbal levels. Language training includes cognitive skills and sound comprehension (social skills and communication skills). 6) In the vocabulary section, vocabulary, simple sentences, and complex sentences are assumed. At the non-verbal level, language training was performed on classifications, arrangement of serial cards, etc. (41).

Speech development occurs as a result of increased listening accuracy and language comprehension. The training at this level includes the production of sounds, using vocabulary to name places, time, objects, concepts, etc., increasing sentence length and explaining visual cards, improving speech content based on linguistic knowledge and children's daily culture and vocabulary. 4) Comprehension: the last level involves auditory training: A) com- 
prehension of common expressions, B) comprehension of one-part and two-part commands, C) comprehension of successive events in a short story (42) that are consistent with the principles of auditory training in children with a cochlear implant (43). One study showed that children with cochlear implants had increased communication and improved communication through a special rehabilitation program that was associated with increased vocabulary.(44) A study by Jalilavand et al. shows that various factors, including early implantation, implantation age below One year, chronological age and age of hearing, use of implantation of two ears, implantation in the right ear, age of diagnosis of deafness, hearing residue before surgery, duration of implantation, features of adult speech, special cooperation of parents and their verbal communication. The use of hearing aids before cochlear implantation, individual differences, socio-economic factors, lack of other disabilities, recognition of disability, memory and attention are all factors affecting the development and development of speech and language in children with cochlear implantation (45). In the study of Mehrakian et al., voice recognition in children with cochlear implants who used the FM device was much better than those who did not use this technology (46); so, it seems that children with cochlear implants need to upgrade cochlear implants and benefit. Few studies in Iran have done on this field; so, it seems necessary that different engineering teams take new steps in this field.

\section{Conclusion}

In summary, for cochlear implantation to achieve its ultimate goal, i.e., complete improvement of speech and benefiting from the auditory sense, a lot of facilities, human, and environmental factors should be combined, such as a full rehabilitation team including a speech therapist, audiologist, psychologist, occupational therapist, etc. along with training families and using various techniques to improve the children's condition such as creative-play, story-telling, use of music, cued speech, various auditory training programs, and family-centered programs to educate families. Speech therapy and auditory training have the highest share of rehabilitation, indicating the importance of this type of rehabilitation. Therefore, the expansion of speech therapy rehabilitation centers seems necessary and is recommended. Rehabilitation equipment also plays an important role in children's hearing and communication with cochlear implants. Further studies are recommended, considering the importance of the family roles in the rehabilitation of these children. The current study lacked the full text of some studies. Given the variety of articles in different fields of rehabilitation, further studies are recommended to pave the way for systematic review and meta-analysis studies and provide more accurate results in each area.

\section{Acknowledgment}

This research is the result of a nursing Ph.D. dissertation with a code of ethics IR.USWR.REC.1397.008, approved and supported by the University of Social Welfare and
Rehabilitation Sciences. The authors appreciate the university heads and library and IT staff who provided the conditions for the research.

\section{Conflict of Interests}

The authors declare that they have no competing interests.

\section{References}

1. WHO. Community based rehabilitation: promoting ear and hearing care through CBR: ed. Geneva: WHO Press, 2012.

2. WHO, Hearing loss control Deafness and hearing loss. Contract No: Document Number, 2017.

3. Iranian deafness, ear, throat, nose and head and neck Research Center (Center of Excellence), in collaboration with the National Institute of Health Research and the Center for Non-Communicable Disease Control of the Ministry of Health. 2012-2015; 5.

4. Spencer PE M, M, editor. Cochlear implants: Issues and implications 2003.

5. Samadi J. Adult cochlear implant. Audial. 2003;20(21):52-5.

6. www.navayesh.ir.

7. Christiansen J, Leigh IW, Spencer PE. History of cochlear implants. Cochlear implants in children: Ethics and choices.2002:15-44.

8. Eisenberg LS. The contributions of William F. House to the field of implantable auditory devices. Hear Res. 2015; 322:52-56.

9. Farhadi M, Daneshi A, Imamjomeh H. Cochlear implantation in Iran. Med J Islam Repub Iran. 1994;.8(2):71-74.

10. Www. komakcharity.com.

11. Dianne J, (ed.), Cochlear Implant rehabilitation in children and adults, London: Whurr publishers; 1996.

12. Riyahi A, Rassafiani M, Rafiei F. Family-Centered Services by Medical and Rehabilitation Staff: A Descriptive Study. J Rehabil 2019:16-27.

13. Rodríguez MM. Alicia Huarte Irujo, Organisation of a Cochlear Implant Programme. Acta Otorrinolaringol Esp. 2013;64(1):55-67.

14. Preben Home TA, Grøntved A, Percy-Smith L, Bille M. Experience with cochlear implants in Greenlanders with profound hearing loss living in Greenland. Int J Circumpollar Health. 2013;209:72-4.

15. Clark J, Yeagle J, Jennifer Y, Arbaje A, Lin F, Niparko J, et al. Cochlear Implant Rehabilitation in Older Adults: Literature Review and Proposal of a Conceptual Framework Am Geriatr Soc. 2012;60(10):1936-45.

16. Quittner AL, Steck JT, Rouiller RL. Cochlear implants in children: a study of parental stress and adjustment. Am J Otol. 1991;12: 95-104

17. Jeddi Z, Jafari Z, Motasaddi Zarandy M. Effect of Aural Rehabilitation on Speech and Cognition Development in Children with Cochlear Implant. Adv Cog Scii. 2012;14(2).

18. Abdi S, Khalessi MH, Khorsandi M, Gholami B. Introducing music as a means of habilitation for children with cochlear implants. Int $\mathrm{J}$ Pediatr Otorhinolaryngol. 2001;59( 2):105-113.

19. Fathi Azar E, Adib Y, Mohebi M. The experiences of mothers with deep hearing loss after cochlear implantation A Phenomenological Study. Except Educ Train. 2016;138(1).

20. Hu X, Zhai L, Long M, Liang W, Wang F, Huo E, et al. Analysis of influencing factors on rehabilitation effects for 1422 preschool deaf children following cochlear implantation. Chin J Otorhinolaryngol Head Neck Surg. 2016;51(5):361-366.

21. Peter VP, Gail MW. Hearing and Deafness,An Introduction for Health and Education Professionals. Jonse and bartlett publishers. 2011.

22. Tye-Murray N. Foundations of aural rehabilitation: Children, adults, and their family members, Clifton Park, NY: Delmar. 2009.

23. Cook CR GF, Kern L, Barreras RB, Thornton S, Crews SD. Social skills training for secondary students with emotional and/or behavioral disorders: a review and analysis of the meta-analytic literature. J Emot Behav Disord. 2008;16(3):131-44.

24. Ghafari S, Fallahi Khoshknab M. Design model of rehabilitation care in patients with multiple sclerosis, Ph.D Dissertation in Nursing in university of social welfare and rehabilitation sciences, 2013.

25. http://www.who.int/disabilities/world_report/2011/chapter4.pdf? ua $=1$.

26. Riyasi M, Dastgheib S. Utilization of basic musical concepts to 
accelerate language acquisition in children after cochlear implantation. Shfaye Khatam. 2013;1(2).

27. Hosseini M, Moradi N, Saki N. The Effect of Combining Music Therapy with Traditional Therapy on Speech Clarity of Children with Cochlear Implant, M.S. thesis, Jundishapur University of Ahvaz. 2016.

28. Mirza-Aghabeyk Sh, Movallali G, Taheri M, Jafari S. The Effect of Cued Speech on Language Skills (Topic Maintenance, Basic Information and Sequence Events of the Story) in Late Implanted PreLingual Hearing Impaired Students: The Benefits of Persian Cued Speech. Rehabilitation. 2015:16(1).

29. Koo D, Crain K, La Sasso CJ, Eden GF. Phonological awareness and short term memory in hearing and deaf individuals of different communication backgrounds. J Ann New York Acad Sci. 2008;11(45):83-99.

30. Hassanzadeh S, Nikkhoo F. The Efficacy of NAVAYESH Parentbased Aural Habilitation on Communication Abilities of Deaf Infants who are in Cochlear Implantation Waiting List: An Experience of Early Intervention on Infants with Deafness. Appl Psychol Res. 2016; 7(3):1-18.

31. Moeller MP. Early intervention and language development in children who are deaf and hard of hearing. Pediatrics. 2000;106:3-43.

32. DesJardin JL. Maternal self-efficacy and involvement: Supporting language development in young deaf children with cochlear implants. Unpublished doctoral dissertation, University of California, Los Angeles. 2004.

33. Yoshinaga-Itano C. From screening to early identification and intervention: Discovering predictors to successful outcomes for children with significant hearing loss. J Deaf Stud Deaf Educ. 2003:11-30.

34. Ebrahimi A. Hearing rehabilitation of children with cochlear implant. Except Educ. 2008:146(3).

35. Qasimzadeh S, Kazemian L. Evaluation of the effectiveness of creative-play intervention programs on language skills of children with cochlear implant. Rehabil Med. 2017.

36. Kunkle-Miller C. Potentials and problems in establishing an art therapy program in a residential school for children who are deaf. Am J Art Ther. 1990;29(2).34-41.

37. https://pejvak88.ir

38. Hamedi D, Saranajam S, Mir Ahmadi A, AkbariM, Safari A. Effect of Task-oriented Occupational Therapy Intervention on Balance Performance of Children with Cochlear Implants. J Clin Res Paramed Sci. 2017;6(1).

39. Shirvani S, Jafari Z, Motasaddi Zarandi M, Jalaie S, Mohagheghi H, Tale MR. Emotional Perception of Music in Children With Bimodal Fitting and Unilateral Cochlear Implant. Ann Otol Rhinol Laryngol. 2016;125(6):470-7.

40. Hassanzadeh S, Nikkhoo F. Effect of Navayesh Parent-Based Comprehensive Rehabilitation Program on the Development of Early Language and Communication Skills in Deaf Children Aged 0-2 Years. Rehabilitation. 2017;17(4).

41. Hashemi B, Monshizadeh L, Alipour A. Effects of cochlear implantation and associated rehabilitation services on the development of verbal and non-verbal intelligence of 6-9 years old deaf children with cochlear implants. Koomesh. 2011;41(1).

42. Zamani P, Soleymani Z, Jalaie Sh, Motasaddi ZarandyM. The effects of narrative-based language intervention (NBLI) on spoken narrative structures in Persian-speaking cochlear implanted children: Aprospective randomized control trial. Int J Pediatr Otorhinolaryngol. 2018:141-150.

43. Oryadi Zanjani MM, Hasanzadeh S, Rahgozar M, Shemshadi H, Purdy SC, Mahmudi Bakhtiari B, et al. Comparing the effect of auditory-only and auditory-visual modes in two groups of Persian children using cochlear implants: A randomized clinical trial. Int $\mathrm{J}$ Pediatr Otorhinolaryngol. 2013:1545-1550.

44. Monshizadeha L, Vameghib R, Rahimi M, Sajedi F, Yadegari F, Hashemi B. The effectiveness of a specifically-designed language intervention protocol on the cochlear implanted children's communication development. Int $\mathrm{J}$ Pediatr Otorhinolaryngol. 2019;126:109-631

45. Jalilevand N. A review on the speech and language development of deaf children who receive cochlear implantation. J Res Rehabil Sci. 2013;9(8):1323-1332.

46. Mehrkian S, Bayat Z, Javanbakht M, Emamdjomeh H, Bakhshi E. Effect of wireless remote microphone application on speech discrimination in noise in children with cochlear implants. J Pediat Otorhinolaryngol. 2019;126:192-195.

47. Shah Panah M, Hatami M, Nouri R. Impact of Music Therapy Measures to Boost up Reading Skills among School Children with Cochlear Implants Rehab Med. 2018;6(4):39-47.

48. Amrayi K, Hassanzadeh S, Afrooz G, Pirzadi H. The effect of family-oriented social skills training program on cochlear implant users. Audiol. 2012;21(3):103-109.

49. Jeddi Z, Jafari Z, Motasaddi Zarandy M, Kassani A. Aural rehabilitation in children with cochlear implants: a study of cognition, social communication, and motor skill development. Cochlear Implants Int. 2014;15(2):93-100.

50. Manouchehri N, Adel Ghiahraman M, Mobedshahi F, MotesadiZarandi M, Rovshan B. Improvement of speech perception in children with cochlear implant. Audiol. 2011;20(2):30-37.

51. Hashemi B, Monashizadeh L, Monbati S. Evaluation of the developmental stages of hearing, language, and speech skills of 30 children with cochlear implant in Fars Province. Iran J Otorhinolaryngol. 2007;18(46).

52. MacDermid JC. An introduction to evidence-based practice for hand therapists. J Hand Ther. 2004 Apr 1;17(2):105-17. 